\title{
ANALISIS PERILAKU STRUKTUR BETON DAN BAJA DENGAN METODE LEVELLING TIME HISTORY (STUDI KASUS GEDUNG E ITERA, LAMPUNG, INDONESIA)
}

\author{
Ahmad Yudi*1 ${ }^{*}$ Bayzoni $^{2}$, Nugraha Bintang Wirawan ${ }^{1}$, Rijuli Nadeak ${ }^{3}$ \\ ${ }^{1}$ Dosen, Program Studi Teknik Sipil, Jurusan Teknologi Infrastruktur dan Kewilayahan, \\ Institut Teknologi Sumatera \\ ${ }^{2}$ Dosen, Program Studi Teknik Sipil, Fakultas Teknik, Universitas Lampung \\ ${ }^{3}$ Mahasiswa, Program Studi Teknik Sipil, Jurusan Teknologi Infrastruktur dan \\ Kewilayahan, Institut Teknologi Sumatera \\ *Korespodensi: ahmad.yudi@si.itera.ac.id
}

\begin{abstract}
The selection of structural material types can be based on analyzing the behavioral of the structure by giving a nonlinear dynamic earthquake load of time history. Because in Indonesia doesn't have any data of time history record, it is necessary to match the time history data with the design spectrum response. Gedung E ITERA is modeled on reinforced concrete structures and steel structures with open frame models for the same as built drawing. Then can be evaluated the structural behavior that is like mass participation, plastic design, displacement, rotation, and base shear with time history load that will be levelling (levelling time history). With levelling the time history load, it can be found the first structural part that collapses and the maximum load that can be retained by the structure for one of the mitigation effort. The analysis uses a nonlinear dynamic time history analysis with the most dominant combination is earthquake combination. The results of this study show the differences in structural performance, the location of structural failure, and the maximum load that can be retained by the reinforced concrete structure and steel structure of gedung E Itera.
\end{abstract}

Keywords: nonlinear dynamic, earthquake, open frame, time history load.

\section{PENDAHULUAN}

Percepatan pembangunan dalam bidang teknologi oleh pemerintah pusat untuk kesiapan akan sumber daya manusia di Sumatera merupakan cikal bakal terbentuknya kampus Institut Teknologi Sumatera. Kampus ini terletak pada provinsi Lampung yang berada pada ujung bawah pulau Sumatera. Penerimaan mahasiswa yang terus kian meningkat tentunya membutuhkan fasilitas-fasilitas penunjang kuliah, salah satu yang paling mendasar yaitu gedung perkuliahan. Sejak diresmikan pada 2014 silam Institut Teknologi Sumatera telah memiliki beberapa gedung utama yang digunakan baik untuk ruang kuliah maupun ruang administrasi kampus. Salah satu gedung yang baru diresmikan pada tahun 2017 adalah Gedung E ITERA yang merupakan hibah gedung dari pemerintah kota Bandar Lampung kepada Institut Teknologi Sumatera demi menunjang kelancaran perkuliahan.

Pada saat ini struktur gedung yang sering diterapkan pada bangunan adalah struktur beton monolit, struktur beton pracetak dan struktur baja. Ketiga jenis struktur ini memiliki keunggulan masing-masing dalam hal penerapannya, baik dari segi ekonomis maupun segi perilaku struktur. Di Institut Teknologi Sumatera sendiri struktur gedung yang diterapkan adalah jenis beton bertulang. Penggunaan beton bertulang pada gedung perkuliahan ini menimbulkan tanya mengapa struktur yang diterapkan adalah beton bertulang, sementara teknologi yang ada sudah memungkinkan penggunaan beton pracetak atau struktur baja.

Salah satu gedung perkuliahan di ITERA yang kapasitasnya cukup besar adalah gedung E ITERA. Gedung berlantai empat dan 
memiliki basement ini juga menggunakan beton bertulang. Banyak faktor yang dapat digunakan sebagai parameter untuk menilai jenis struktur gedung yang paling optimum. Salah satu faktor yang paling sering digunakan adalah faktor ekonomis yang berkaitan dengan efisiensi material yang akan digunakan. Selain itu faktor kemampuan layan juga berperan penting karena dengan berbagai beban yang akan diterima struktur harus dipastikan struktur bangunan tetap aman.

Dalam studi kali ini penulis ingin membandingkan dua jenis struktur dengan desain arsitektur yang sudah ada. Gedung yang digunakan untuk studi kasus ini adalah salah satu gedung perkuliahan yang ada di ITERA yaitu gedung E ITERA. Jenis struktur yang akan dibandingkan adalah struktur beton dan struktur baja. Tinjauan yang akan dilakukan untuk membandingkan struktur yang lebih baik adalah dengan meninjau perilaku struktur dari jenis struktur yang diterapkan.

Salah satu cara untuk mendapatkan hasil dari perilaku struktur adalah dengan memberikan gaya-gaya pada struktur. Salah satu gaya yang tingkat abstraksinya tinggi adalah gaya gempa yang sangat tidak teratur dan durasinya juga sangat acak. Bentuk penyederhanaan gaya gempa ini dapat berupa respons spektrum dan time history analisis. Pada penelitian ini beban gempa yang digunakan adalah beban time history yang telah dimatching dengan respons spektrum daerah lampung. Beban gempa time history ini ditingkatkan Aog-nya (percepatan awal gempa) secara bertahap sampai memperoleh semua struktur sudah gagal agar dapat melihat perilaku struktur secara bertahap. Metode pembebanan yang sama akan digunakan pada masing-masing struktur beton dan struktur baja untuk studi kasus gedung E ITERA.

\section{TINJAUAN PUSTAKA}

\subsection{Daktilitas}

Daktilitas adalah kemampuan suatu struktur gedung untuk mengalami simpangan pasca elastik yang besar secara berulang kali dan bolak-balik akibat beban gempa di atas beban gempa yang menyebabkan terjadinya pelelehan pertama sambil mempertahankan kekuatan dan kekakuan yang cukup sehingga struktur gedung tersebut tetap berdiri walaupun sudah berada dalam kondisi di ambang keruntuhan [1]. Pada struktur berdeformasi bisa berarti memanjang, memendek, dan bengkok. Faktor daktilitas suatu struktur gedung merupakan dasar bagi penentuan beban gempa yang bekerja pada struktur gedung, karena itu tercapainya tingkat yang diharapkan harus terjamin dengan baik. Hal ini dapat tercapai apabila balok harus leleh terlebih dahulu sebelum terjadi kerusakan-kerusakan pada kolom(konsep strong coloumn weak beam). Hal ini berarti bahwa akibat pengaruh gempa rencana, sendi-sendi plastis di dalam struktur gedung hanya berada pada ujung-ujung balok dan pada kaki-kaki kolom.

Dalam pengertian yang lebih lagi daktilitas merupakan kemampuan struktur untuk mengalami simpangan pasca elastik yang besar secara berulang kali dan bolak-balik akibat adanya beban gempa yang menyebabkan terjadinya pelelehan pertama, sambil mempertahankan kekuatan dan kekakuan yang cukup, sehingga struktur itu tetap berdiri walaupun sudah berada pada kondisi ambang keruntuhan. Dalam perencanaan bangunan tahan gempa, terbentuknya sendi-sendi plastis yang diharapkan terjadi pada struktur saat terjadi gempa yang besar perlu dikontrol dan dibatasi lokasinya pada komponen struktur tersebut. Pada struktur rangka akan lebih baik apabila disipasi energi gempa melalui pelelehan (sendi plastis) pada komponen balok dan kolom yang diharapkan memberikan kekuatan, kekakuan, dan kestabilan pada waktu menahan gaya-gaya yang bekerja melalui aksi lentur, geser, dan aksial. Sistem rangka ruang di dalam komponen-komponen struktur dan join-joinnya menahan gaya-gaya yang bekerja melalui aksi lentur, geser dan aksial disebut dengan Sistem Rangka Pemikul Momen.

\subsection{Struktur Bangunan Gedung Beraturan dan Tidak Beraturan}

Menurut SNI 1726-2012 pasal 7 [2] struktur bangunan gedung harus diklasifikasikan sebagai struktur gedung beraturan dan struktur gedung tidak beraturan. Untuk struktur gedung beraturan dapat digunakan prosedur analisis statis ekuivalen dan untuk struktur gedung tidak beraturan, pengaruh gempa rencana harus ditinjau sebagai pengaruh pembebanan dinamik. Analisis yang dapat digunakan untuk struktur gedung tidak beraturan adalah analisis ragam respons spektrum dan analisis respons dinamik riwayat waktu linier dan nonlinier. 
Pada penelitian ini digunakan perencanaan struktur gedung tidak beraturan dengan analisis yang digunakan adalah analisis respons dinamik riwayat waktu.

\subsection{Akselogram Gempa Time History}

Beban gempa dinamik dapat dianalisis menggunakan analisis dinamik. Dan untuk beban time history menggunakan analisis riwayat waktu yang dijelaskan seperti di bawah ini :

1. Analisis Dinamik

Analisis dinamik adalah analisis struktur di mana pembagian gaya geser gempa di seluruh tingkat diperoleh dengan memperhitungkan pengaruh dinamis gerakan tanah terhadap struktur. Analisis dinamik terbagi menjadi 2 [3], yaitu :

1) Analisis ragam respons spektrum di mana total respons didapat melalui superposisi dari respons masing-masing ragam getar.

2) Analisis riwayat waktu adalah analisis dinamis di mana pada model struktur diterapkan percepatan gempa dari masukan berupa akselogram dan respons struktur dihitung langkah demi langkah pada interval tertentu.

2. Analisis Riwayat Waktu

Menurut Chopra [4], Analisa Riwayat waktu digunakan untuk menganalisis respons dinamik struktur yang menerima beban yang berubah-ubah terhadap waktu. Persamaan dinamik dari struktur seperti ini dapat dilihat pada persamaan 1 .

$$
[M] \ddot{\mathrm{u}}(\mathrm{t})+[C] \dot{\mathrm{u}}(\mathrm{t})+[K] u(t)=\{p(t)\}
$$

Di mana $[M]$ adalah matriks massa struktur; $[C]$ adalah matriks redaman struktur; $[K]$ adalah matriks kekakuan struktur; $\mathrm{u}(\mathrm{t})$ adalah simpangan yang berubah terhadap waktu; $u(t)$ adalah kecepatan yang berubah terhadap waktu; $\ddot{u}(t)$ adalah percepatan dari struktur yang berubah terhadap waktu; dan $p(t)$ adalah vektor gaya yang bekerja pada struktur yang berubah terhadap waktu. Analisis riwayat waktu dibagi atas dua yaitu analisis riwayat waktu linier dan analisis riwayat waktu nonlinier.

Struktur linear adalah struktur yang tidak mengalami perubahan Massa $(M)$, Redaman $(C)$, dan Kekakuan $(K)$ dalam kondisi apapun. Analisa dalam kondisi ini biasanya digunakan dengan asumsi bahwa struktur direncanakan selalu berada dalam kondisi elastis, atau sifat struktur dapat kembali ke posisi awal setelah diberikan beban tertentu. Struktur yang diberi analisis nonlinear adalah struktur yang mengalami perubahan Redaman (C), dan Kekakuan (K) pada kondisi tertentu. Analisa seperti ini membantu untuk memahami bagaimana sifat suatu struktur tersebut dapat bertahan. Nilai perbandingan titik hancur pertama kali leleh struktur disebut daktilitas $(\mu)$.

3. Percepatan Gempa Masukan (Akselerogram)

Sebelum menerapkan rangkaian akselogram dalam analisis struktural, data harus diskalakan untuk mengurangi ketidakcocokan antara karakteristik dan parameter desain di suatu wilayah berdasarkan standar atau dari situs hazard tertentu. Hal yang perlu diingat bahwa akselogram digunakan mewakili gerakan gempa.

Periode alami (natural period) dari getaran struktur selalu ditentukan dengan tingkat ketidakpastian (degree of uncertainly). Penggunaan hanya satu akselogram dalam analisis struktural dapat dengan mudah diremehkan (underestimation). Untuk alasan ini, jumlah minimum variasi karakteristik dari suatu akselogram lain yang mungkin dianggap akan mengurangi pengaruh fluktuasi periode ke periode dalam spectra. Maka dari itu analisis riwayat waktu harus dilakukan dengan tidak kurang dari tiga set data (masing-masing berisi dua komponen horizontal atau, jika gerakan vertikal dipertimbangkan, dua komponen horizontal dan satu komponen vertikal) dari gerakan tanah (ground motion) yang harus dipilih dan skala tidak kurang dari tiga catatan gempa [5].

Akselogram yang dipilih dalam analisis time history pada level gempa rencana harus memenuhi persyaratan seperti yang ditetapkan dalam Pasal 11.1.3.2, SNI-1726-2012 yaitu respons spektrum dari gempa aktual (redaman $5 \%$ ) yang dipilih sebagai gerak tanah masukan, rata-rata nilai percepatannya harus berdekatan dengan respons spektrum dari gempa rencana (redaman 5\%) pada periode $0,2 \mathrm{~T}-1,5 \mathrm{~T}$ [2]

\subsection{Sendi Plastis}

Mekanisme sendi plastis terbentuk di ujung-ujung dan di dasar kolom bawah menghasilkan perilaku histeresis yang stabil, 
pembentukan sendi plastis haruslah didominasi oleh perilaku lentur. Sendi plastis dapat terjadi pada suatu portal berderajat kebebasan banyak (MDOF). Gedung saat dilanda gempa yang cukup besar akan timbul momen-momen pada balok atau kolomnya, apabila besar dari momen-momen tersebut melampaui besar momen kapasitas balok atau kolom portal maka terjadi sendi plastis pada balok atau kolom ditandai dengan melelehnya tulangan baja pada beton bertulang. Sendi plastis terjadi secara bertahap sampai bangunan gedung tersebut runtuh [6].

Struktur didesain untuk mengalami kerusakan atau berprilaku inelastik melalui pembentukan sendi-sendi plastis pada elemen-elemen strukturnya, pada saat menahan beban gempa rencana. Perilaku inelastik atau plastis tersebut pada dasarnya memberikan mekanisme disipasi energi pada struktur sehingga dapat membatasi gaya gempa yang masuk ke struktur bangunan. Walaupun struktur bangunan berprilaku inelastik, struktur bangunan tidak boleh mengalami keruntuhan pada saat menerima beban gempa rencana atau bahkan beban gempa yang lebih besar [7].

Berdasarkan FEMA 356 hubungan gaya dan perpindahan dapat dikategorikan ke dalam beberapa kriteria yang menunjukkan perilaku sendi plastis. Hubungan gaya dan perpindahan dalam bentuk grafik adalah seperti pada Gambar 1 :

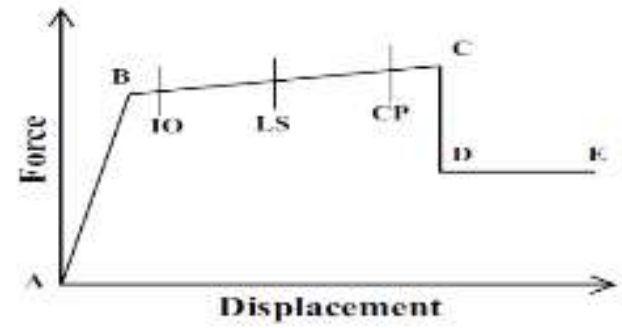

Gambar 1. Tahapan Performa Struktur Sumber : CSI 2014

Structural performance dikategorikan menjadi 3 rentang yaitu :

IO : Immediate Occupancy

LS : Life Safety

$\mathrm{CP} \quad$ : Collapse Prevention

Immediate Occupancy berarti kondisi ketika tidak ada kerusakan yang berarti pada struktur di mana kekuatan dan kekakuannya kira-kira hampir sama dengan kondisi sebelum gempa. Life Safety berarti kondisi ketika terjadi kerusakan komponen struktur, kekakuan berkurang, tetapi masih mempunyai ambang yang cukup terhadap keruntuhan, komponen nonstruktur masih ada tetapi tidak berfungsi dan dapat dipakai lagi jika sudah dilakukan perbaikan. Collapse Prevention berarti kondisi di mana kerusakan yang berarti pada komponen struktur dan nonstruktur, kekuatan struktur berkurang banyak dan hampir mengalami keruntuhan.

\subsection{Simpangan}

Berdasarkan FEMA 356, rasio batasan simpangan untuk ketiga kategori Immediate Occupancy, Life Safety, dan Collapse Prevention seperti yang terdapat pada Tabel 1.

Tabel 1. Kriteria Simpangan (displacement)

\begin{tabular}{c|c|c|c}
\hline Sistem Struktur & IO & LS & CP \\
\hline Beton & $1 \%$ & $2 \%$ & $4 \%$ \\
\hline Baja & $0,7 \%$ & $2,5 \%$ & $5 \%$ \\
\hline
\end{tabular}

\subsection{Rotasi}

Berdasarkan FEMA 356 batasan rotasi pada struktur beton yang diizinkan untuk kondisi Immediate Occupancy, Life Safety, dan Collapse Prevention adalah seperti yang terdapat pada Tabel 2.

Table 2. Rotasi Diizinkan pada Struktur Beton (dalam radian)

\begin{tabular}{c|c|c|c|c|c|c}
\hline Sistem & \multicolumn{2}{|c|}{ IO } & \multicolumn{2}{c|}{ LS } & \multicolumn{2}{c}{ CP } \\
\cline { 2 - 7 } Struktur & $(+)$ & $(-)$ & $(+)$ & $(-)$ & $(+)$ & $(-)$ \\
\hline Balok & 0,01 & $-0,01$ & 0,02 & -0.02 & 0,025 & -0.025 \\
\hline
\end{tabular}

Sedangkan untuk struktur baja, batasan rotasi yang diizinkan untuk masing-masing kondisi Immediate Occupancy, Life Safety, dan Collapse Prevention adalah seperti yang terdapat pada Tabel 3.

Tabel 3. Rotasi Diizinkan pada Struktur Baja (dalam radian)

\begin{tabular}{c|c|c|c|c|c|c}
\hline \multirow{2}{*}{$\begin{array}{c}\text { Sistem } \\
\text { Struktur }\end{array}$} & \multicolumn{2}{|c|}{ IO } & \multicolumn{2}{c|}{ LS } & \multicolumn{2}{c}{ CP } \\
\cline { 2 - 7 } & $(+)$ & $(-)$ & $(+)$ & $(-)$ & $(+)$ & $(-)$ \\
\hline Balok & 0,00175 & $-0,0017$ & 0,014 & $-0,014$ & 0,021 & $-0,021$ \\
\hline
\end{tabular}

\section{METODE PENELITIAN}

\subsection{Diagram Alir}

Urutan proses pelaksanaan penelitian tugas akhir ini dapat dilihat pada Gambar 2. 


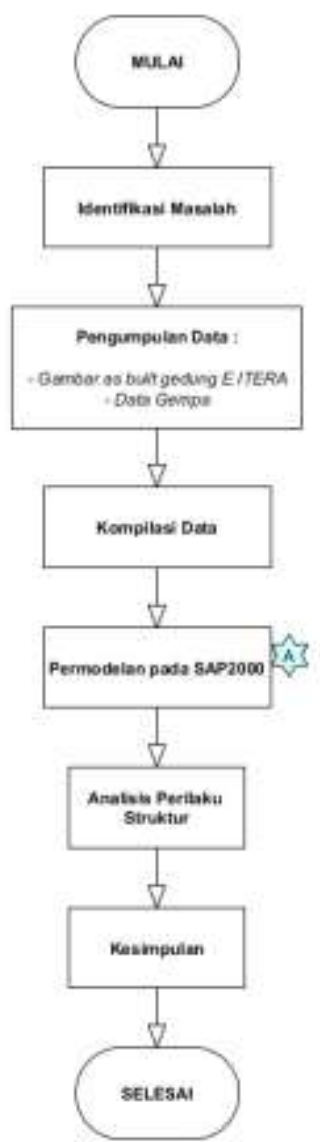

Gambar 2. Diagram Alir

Permodelan pada SAP2000 dijelaskan pada Gambar 3 :

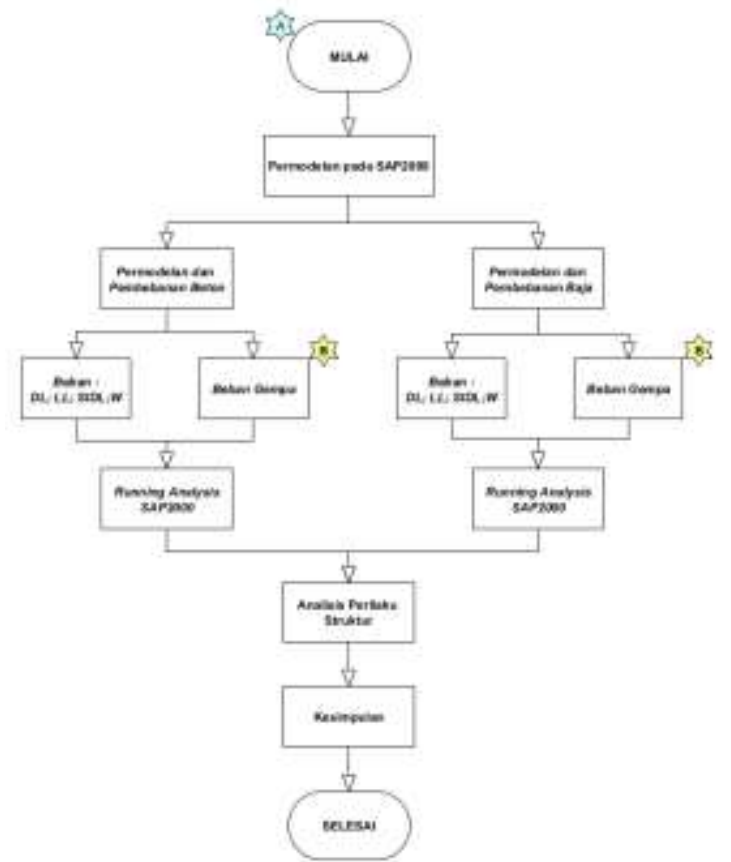

Gambar 3. Diagram Alir Permodelan Pada SAP2000
Proses dan tahapan beban gempa yang digunakan pada penelitian ini diuraikan pada Gambar 4.

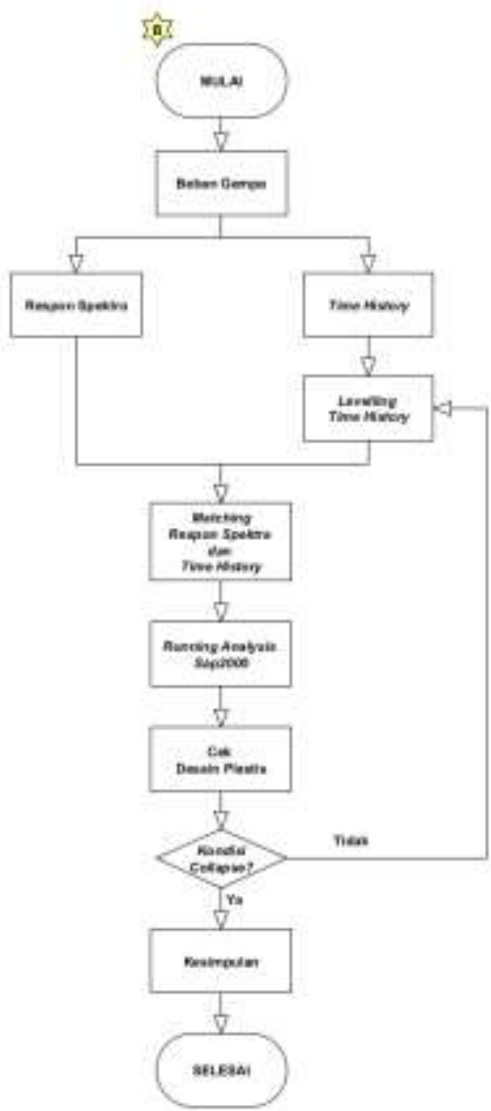

Gambar 4. Diagram Alir Beban Gempa

\subsection{Identifikasi Masalah}

Dalam penelitian ini identifikasi masalah merupakan langkah awal dalam menentukan pentingnya penelitian ini dilakukan. Dan pada tahap ini permasalahan yang muncul adalah wilayah Indonesia yang terletak di kawasan yang acap kali terjadi gempa. Gempa yang terjadi akan menjadi beban yang akan diterima oleh suatu struktur dan dan harus dipastikan struktur bangunan yang bilamana terjadi gempa di sekitarnya harus tetap aman. Struktur yang umumnya digunakan pada konstruksi gedung adalah struktur beton, struktur beton pracetak, dan struktur baja yang dalam hal ini gedung $\mathrm{E}$ ITERA sudah dibangun menggunakan struktur beton bertulang. Tidak menutup kemungkinan gedung-gedung lain yang akan dibangun di Institut Teknologi Sumatera akan menggunakan material lain seperti struktur baja. Karena salah satu yang harus diperhitungkan dalam merencanakan suatu struktur adalah beban gempa yang akan diterima oleh struktur, maka dengan memberikan beban gempa yang 
berbeda-beda akan dapat dilihat performa dari suatu struktur.

\subsection{Pengumpulan Data}

Penelitian ini membutuhkan data-data penunjang yang akan digunakan. Data-data tersebut berupa data struktur gedung E ITERA (eksisting) yang akan dibahas lebih detail pada subbab input data struktur. Selain itu data gempa juga dibutuhkan dalam penelitian ini yang merupakan data gempa respons spektrum desain dan data gempa Loma Prieta AGM02.

\section{HASIL DAN PEMBAHASAN}

\subsection{Deskripsi Struktur}

Seperti yang telah dibahas sebelumnya bahwa pada penelitian ini menggunakan dua jenis struktur material yaitu : beton bertulang (eksisting) dan struktur baja. Dengan desain struktur beton bertulang yang disesuaikan dengan gambar as built gedung E ITERA dan desain struktur baja yang merupakan hasil dari desain trial and error. Desain struktur baja yang merupakan hasil dari trial and error tetap dibuat sesuai dengan denah gambar as built gedung E ITERA.

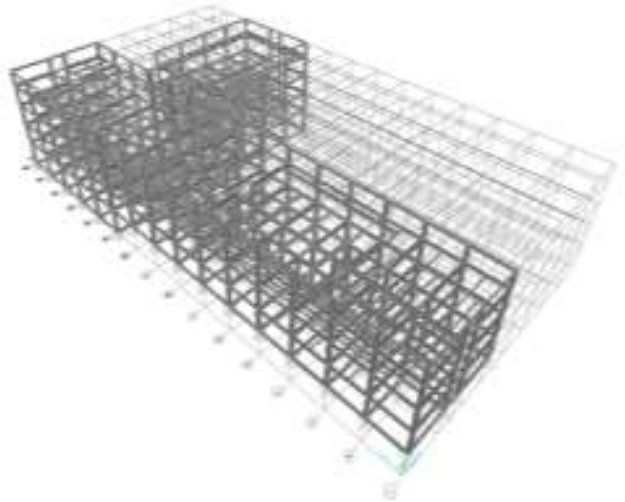

Gambar 5. Tampak 3D Sistem Struktur Gedung E ITERA

\subsection{Proses Matching dan Levelling}

Pada penelitian ini dilakukan pencocokan (matching) rekaman gempa dengan terlebih dahulu dikalikan dengan suatu bilangan sehingga respons spektrum dari akselogram mendekati respons spektrum berdasarkan SNI untuk daerah Lampung dengan kondisi tanah lunak.

Data hasil perkalian yang merupakan data percepatan dan waktu akan dilakukan penggambaran menggunakan bantuan software Seismosignal dari Seismosoft sehingga didapatkan hasil plot rekaman AGM02. Data keluaran dari seismosignal tersebut merupakan data percepatan terhadap waktu yang sudah disesuaikan dengan respons spektrum lokasi gedung E ITERA berada. Tampilan dari perbandingan antara kurva respons spektrum berdasarkan SNI dan time history yang sudah dicocokkan dapat dilihat pada Gambar 6.

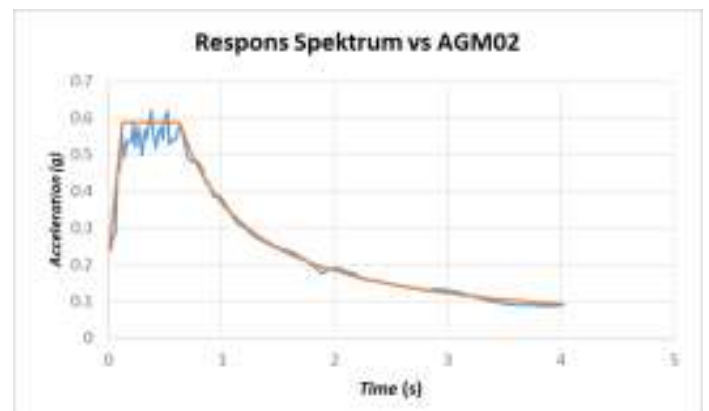

Gambar 6. Matching Time History dan Respons Spektrum

Pada analisis menggunakan SAP2000 rekaman gempa AGM02 yang sudah dicocokkan dengan respons spektrum daerah lampung akan dilakukan peningkatan Aog (percepatan gempa) beberapa kali dan contohnya dapat dilihat pada Gambar 7 . Peningkatan percepatan awal gempa bertujuan untuk melihat performa (perilaku struktur) beton dan baja gedung E ITERA di setiap peningkatan Aog.

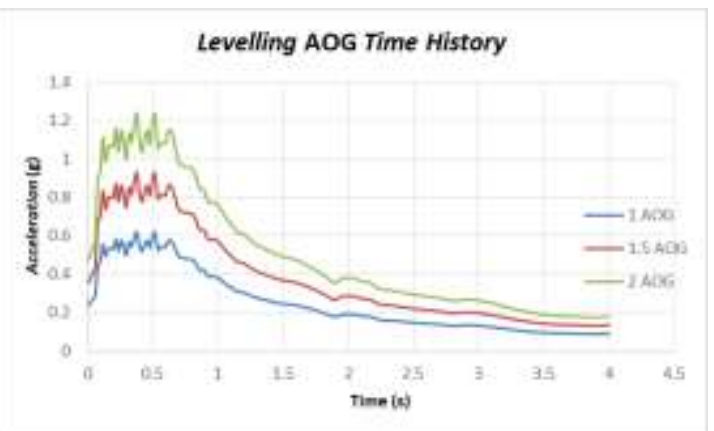

Gambar 7. Hasil Levelling Aog Time History

\subsection{Analisis Stuktur}

\subsubsection{Cek Partisipasi Massa}

Pengecekan partisipasi massa dilakukan untuk mengetahui pada kondisi mode (ragam getar) berapa struktur mengalami partisipasi massa mencapai $90 \%$ (sesuai dengan SNI 1726-2012). Di mana mode tersebut digunakan sebagai acuan penentuan pola gerak yang dominan. 
Tabel 4. Partisipasi Massa Struktur Beton

\begin{tabular}{|c|c|c|c|c|c|c|c|c|c|c|}
\hline \multirow{2}{*}{ Moode } & \multirow{2}{*}{$\begin{array}{c}\mathrm{T} \\
\text { (second) }\end{array}$} & \multicolumn{9}{|c|}{ Mass Participation (\%) } \\
\hline & & ix & UX & Shape & iy & UY & Shape & $\mathrm{iz}$ & $\mathbf{U Z}$ & Shape \\
\hline 1 & 0.935855 & 51.0620 & 51.062 & & 0.042 & 0.042 & & 67.209 & 67.209 & \\
\hline 2 & 0.875618 & 0.1990 & 51.261 & & 17.046 & 17.089 & & 5.18 & 72.389 & \\
\hline 3 & 0.771157 & 0.0800 & 51.341 & & 0.344 & 17.432 & & 1.119 & 73.508 & \\
\hline 4 & 0.754685 & 0.0009 & 51.342 & & 33.462 & 50.894 & & 1.515 & 75.023 & \\
\hline 5 & 0.676395 & 0.0051 & 51.347 & & 24.614 & 75.509 & & 0.16 & 75.183 & \\
\hline 6 & 0.63096 & 26.1480 & 77.495 & & 0.00098 & 75.51 & & 3.623 & 78.806 & \\
\hline 7 & 0.614702 & 0.1110 & 77.606 & & 0.157 & 75.667 & & 1.731 & 80.537 & \\
\hline 8 & 0.58907 & 1.5840 & 79.19 & & 0.025 & 75.692 & & 1.648 & 82.185 & \\
\hline 9 & 0.561302 & 0.0820 & 79.272 & & 0.021 & 75.713 & & 0.031 & 82.216 & \\
\hline 10 & 0.507839 & 1.5660 & 80.839 & & 0.001 & 75.714 & & 0.328 & 82.544 & \\
\hline 11 & 0.448267 & 2.0180 & 82.857 & & 0.011 & 75.725 & & 2.201 & 84.745 & \\
\hline 12 & 0.438511 & 0.0150 & 82.872 & & 1.828 & 77.554 & & 0.716 & 85.461 & \\
\hline 13 & 0.364047 & 0.6500 & 83.522 & & 1.559 & 79.112 & & 0.091 & 85.552 & \\
\hline 14 & 0.357696 & 3.2970 & 86.819 & & 0.377 & 79.49 & & 1.849 & 87.401 & \\
\hline 15 & 0.30916 & 2.7480 & 89.568 & & 0.016 & 79.506 & & 2.334 & 89.735 & Rotation-Z \\
\hline 16 & 0.255101 & 0.0089 & 89.576 & Translation-X & 6.441 & 85.947 & & 0.41 & 90.145 & Rotation-Z \\
\hline 17 & 0.206031 & 4.7060 & 94.283 & Translation-X & 0.156 & 86.103 & Translation-Y & 2.059 & 92.204 & \\
\hline 18 & 0.193337 & 0.1020 & 94.384 & & 6.055 & 92.158 & Translation-Y & 0.448 & 92.652 & \\
\hline
\end{tabular}

Tabel 5. Partisipasi Massa Struktur Baja

\begin{tabular}{|c|c|c|c|c|c|c|c|c|c|c|}
\hline \multirow{2}{*}{ Moode } & \multirow{2}{*}{$\begin{array}{c}T \\
\text { (second) }\end{array}$} & \multicolumn{9}{|c|}{ Mass Participation (\%) } \\
\hline & & ix & UX & Shape & iy & UY & Shape & iz & UZ & Shape \\
\hline 1 & 0.909629 & 0.0001 & 0.0001 & & 21.256 & 21.256 & & 7.064 & 7.064 & \\
\hline 2 & 0.834771 & 0.0010 & 0.00113 & & 0.326 & 21.583 & & 0.095 & 7.159 & \\
\hline 3 & 0.763924 & 44.4800 & 44.481 & & 1.1E- 05 & 21.583 & & 56.661 & 63.819 & \\
\hline 4 & 0.739606 & 0.0110 & 44.492 & & 0.846 & 22.428 & & 0.514 & 64.333 & \\
\hline 5 & 0.73026 & 0.1830 & 44.675 & & 0.588 & 23.016 & & 0.76 & 65.093 & \\
\hline 6 & 0.720494 & 0.4830 & 45.157 & & 0.105 & 23.121 & & 0.833 & 65.926 & \\
\hline 7 & 0.66782 & 0.8460 & 46.003 & & 0.014 & 23.134 & & 0.558 & 66.484 & \\
\hline 8 & 0.645447 & 0.0000 & 46.003 & & 1.889 & 25.023 & & 0.027 & 66.511 & \\
\hline 9 & 0.635688 & 1.6380 & 47.641 & & 0.357 & 25.38 & & 3.385 & 69.896 & \\
\hline 10 & 0.626294 & 0.0180 & 47.659 & & 43.693 & 69.073 & & 0.525 & 70.421 & \\
\hline 11 & 0.594697 & 0.1270 & 47.786 & & 0.00123 & 69.074 & & 0.064 & 70.485 & \\
\hline 12 & 0.548158 & 0.0300 & 47.816 & & 4.915 & 73.989 & & 0.185 & 70.671 & \\
\hline 13 & 0.524527 & 8.7530 & 56.569 & & 0.924 & 74.913 & & 0.788 & 71.459 & \\
\hline 14 & 0.52174 & 3.7360 & 60.306 & & 2.01 & 76.923 & & 1.398 & 72.856 & \\
\hline 15 & 0.482105 & 0.3070 & 60.612 & & 0.391 & 77.314 & & 0.05 & 72.907 & \\
\hline 16 & 0.468769 & 15.1840 & 75.796 & & 0.00302 & 77.317 & & 3.598 & 76.505 & \\
\hline 17 & 0.394312 & 0.5400 & 76.336 & & 0.00205 & 77.319 & & 0.075 & 76.58 & \\
\hline 18 & 0.324738 & 0.2590 & 76.595 & & 0.275 & 77.594 & & 0.647 & 77.227 & \\
\hline 19 & 0.31492 & 3.522 & 80.117 & & 0.026 & 77.62 & & 3.423 & 80.651 & \\
\hline 20 & 0.252419 & 4.551 & 84.668 & & 0.047 & 77.667 & & 2.187 & 82.838 & \\
\hline 21 & 0.241362 & 0.029 & 84.696 & Translation-X & 7.802 & 85.469 & & 0.334 & 83.172 & \\
\hline 22 & 0.166368 & 6.328 & 91.024 & Translation-X & 0.289 & 85.758 & Translation-Y & 5.738 & 88.91 & \\
\hline 23 & 0.161942 & 0.355 & 91.379 & & 5.341 & 91.099 & Translation-Y & 0.07 & 88.979 & \\
\hline 24 & 0.099331 & 0.351 & 91.731 & & 3.819 & 94.917 & & 0.548 & 89.528 & Rotation-Z \\
\hline 25 & 0.096404 & 4.422 & 96.153 & & 0.262 & 95.179 & & 0.941 & 90.469 & Rotation-Z \\
\hline
\end{tabular}

Dari data di atas dapat diketahui mode struktur beton yang mencapai partisipasi massa $90 \%$ pada 3 pola gerak. Pada pola gerak translasi-x yang sudah mencapai $90 \%$ adalah pada mode 17. Pada arah pola gerak translasi-y partisipasi massa mencapai $90 \%$ terjadi pada mode 18. Dan pada pola gerak rotazi-z partisipasi massa mencapai $90 \%$ terjadi pada mode 16.

Sedangkan pada struktur baja mode yang telah mencapai partisipasi massa $90 \%$ pada arah 3 pola gerak terjadi pada mode yang berbeda. Pada pola gerak translasi-x yang sudah mencapai $90 \%$ adalah pada mode 22 . Pada arah pola gerak translasi-y partisipasi massa mencapai $90 \%$ terjadi pada mode 23 . Dan pada pola gerak rotazi-z partisipasi massa mencapai $90 \%$ terjadi pada mode 25 .

\subsubsection{Cek Desain Plastis}

Pada struktur beton bertulang gedung E ITERA kondisi saat sendi plastis terbentuk sudah melampaui collapse prevention $(\mathrm{CP})$ ini mulai tercapai ketika struktur menerima gempa dengan percepatan awal 2 kali dari percepatan awal gempa $(0,468 \mathrm{~g})$ seperti yang ada pada Gambar 8.

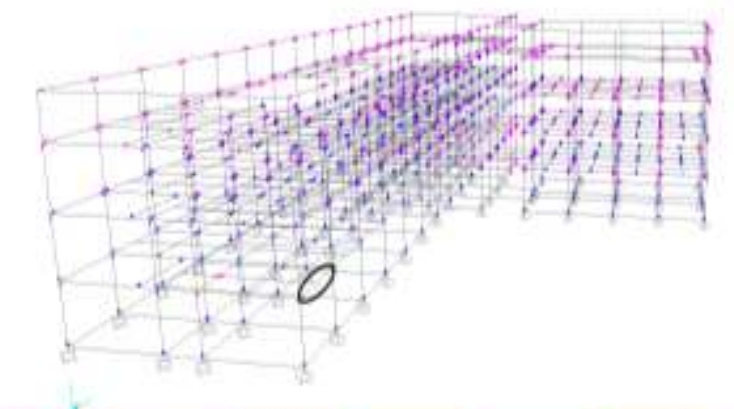

Gambar 8. Indikator Sendi Plastis Struktur
Beton

Ketika struktur beton belum menerima beban gempa maka sendi plastis masih belum terbentuk, dan ketika diberikan beban gempa dengan percepatan gempa awal maka indikator sendi plastis yang terbentuk hampir semua berada pada kondisi warna ungu (batas elastis) dan struktur beton dengan member 208 (yang dilingkari warna hitam pada Gambar 8) merupakan member yang pertama kali mencapai kondisi immediate occupancy (warna biru pada indikator). Hal yang sama terjadi ketika beban gempa ditingkatkan percepatan awal gempanya, perubahan indikator sendi plastis terjadi secara bertahap dan yang selalu mencapai kondisi-kondisi batas pada sendi plastis terlebih dahulu adalah member 208 tersebut.

Member yang digunakan sebagai acuan dalam pengecekan desain plastis adalah member nomor 208 (ditandai di Gambar 8) karena member tersebut yang pertama mengalami keruntuhan yang ditandai dengan perubahan indikator warna sendi plastis. Indikator sendi plastis akan muncul pada kedua ujung member. Member tersebut merupakan balok arah y dengan ukuran penampang 250x500 mm (bxh) pada model struktur beton gedung E ITERA.

Sedangkan pada struktur baja kondisi ketika sendi plastis telah mencapai kondisi di atas CP berada pada saat struktur baja menerima beban gempa dengan percepatan 
awal 3.4 kali percepatan awal gempa $(0,7956 \mathrm{~g})$ seperti yang ada pada Gambar 9.

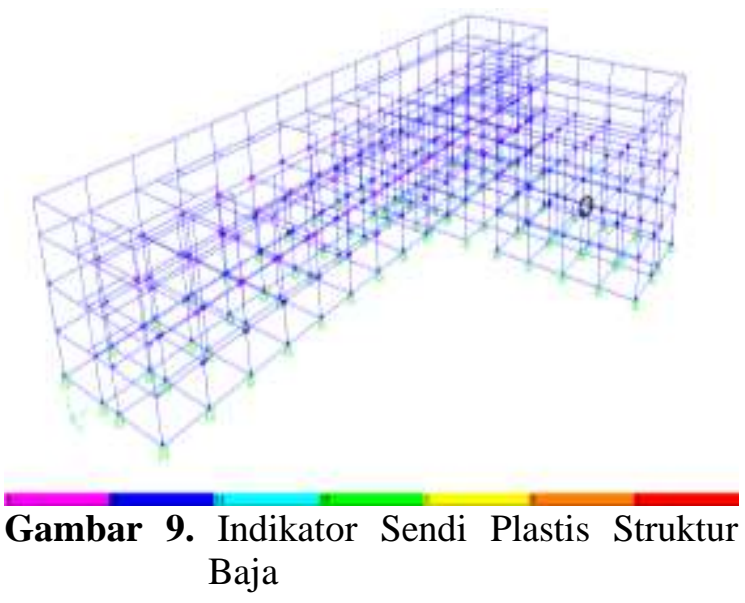

Pada tahap awal ketika struktur baja menerima beban gempa dengan percepatan gempa awal $(0,234 \mathrm{~g})$ hampir semua sendi plastis yang terbentuk menunjukkan kondisi batas elastis, namun salah satu member sudah mencapai kondisi immediate occupancy (warna biru pada indikator) yakni member 130 (yang dilingkari warna hitam pada Gambar 9). Hal yang sama terjadi ketika beban gempa ditingkatkan percepatan awal gempanya, perubahan indikator sendi plastis terjadi secara bertahap dan yang selalu mencapai kondisi-kondisi batas pada sendi plastis terlebih dahulu adalah member 130 tersebut.

Pada struktur baja member yang digunakan sebagai acuan dalam pengecekan desain plastis adalah member nomor 130 (terlihat pada Gambar 9) karena member tersebut yang terlebih dahulu mengalami keruntuhan yang pada SAP ditandai dengan perubahan warna indikator sendi plastis. Indikator sendi plastis akan muncul pada kedua ujung member. Member tersebut merupakan balok dengan penampang profil IWF 300x150 mm pada model struktur baja gedung $\mathrm{E}$ ITERA.

Sendi plastis terbentuk ketika suatu kondisi telah tercapai .Yang dalam hal ini pada aplikasi SAP2000 sendi plastis tersebut terbentuk dan dapat berubah sesuai warna indikator yang ada pada gambar sering dengan terjadi peningkatan nilai rotasi dan momen pada struktur.

\subsubsection{Simpangan}

Berdasarkan SNI 1726-2012 simpangan izin antar lantai (interstory) yaitu sebesar 1,5\% dari tinggi tingkat di bawah tingkat yang ditinjau. Pada struktur beton gedung E ITERA ada 2 titik joint yang diambil sebagai titik tinjauan terhadap simpangan seperti yang terlihat pada Gambar 10, yaitu joint 1128 (J1128) dan joint 709 (J709).

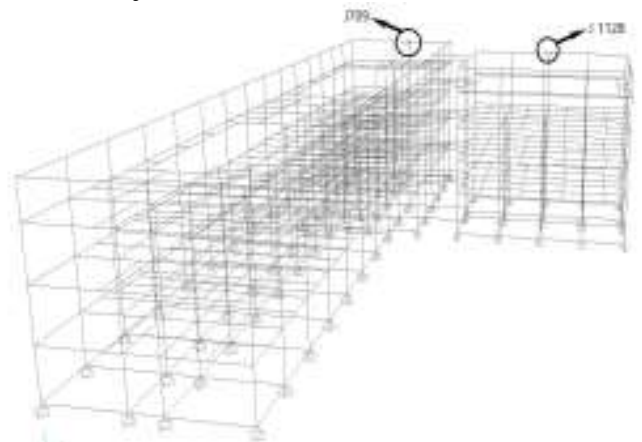

Gambar 10. Joint Struktur Beton yang Ditinjau

Tabel 6. Simpangan Struktur Beton (SNI 1726-2012)

\begin{tabular}{cccc}
\hline \multirow{2}{*}{ PGA (g) } & \multicolumn{2}{c}{ Displacement, $\boldsymbol{S}(\mathbf{m})$} & \multirow{2}{*}{ S limit (m) } \\
& $\mathbf{J 1 1 2 8}$ & $\mathbf{J 7 0 9}$ & \\
\hline $\mathbf{0 . 2 3 4}$ & 0.060381 & 0.018507 & 0.045 \\
$\mathbf{0 . 3 5 1}$ & 0.089083 & 0.028693 & 0.045 \\
$\mathbf{0 . 3 7 4 4}$ & 0.094937 & 0.030719 & 0.045 \\
$\mathbf{0 . 3 9 7 8}$ & 0.100812 & 0.032754 & 0.045 \\
$\mathbf{0 . 4 2 1 2}$ & 0.106752 & 0.034807 & 0.045 \\
$\mathbf{0 . 4 4 4 6}$ & 0.112583 & 0.036816 & 0.045 \\
$\mathbf{0 . 4 6 8}$ & 0.118506 & 0.038874 & 0.045 \\
\hline
\end{tabular}

Dari data pada tabel dapat dilihat struktur beton gedung E ITERA sudah melewati nilai simpangan izin (SNI 1726-2012) pada kasus percepatan gempa $0.234 \mathrm{~g}$ di joint 1128 namun belum melewati simpangan izin pada joint 709 . Hal yang sama terjadi ketika dilakukan peningkatan percepatan gempa (seperti yang terlihat pada Tabel 6).

Dengan menggunakan standar pada FEMA 356 dengan batasan kondisi IO (immediate occupancy) 1\%, LS (life Safety) $2 \%$, dan CP (collapse prevention) sebesar $4 \%$ dari tinggi tingkat dibawah tingkat yang ditinjau maka data simpangan berdasarkan FEMA 356 pada struktur beton dapat dilihat pada Tabel 7. 
Tabel 7. Simpangan Struktur Beton (FEMA 356)

\begin{tabular}{cccccc}
\hline $\begin{array}{c}\text { PGA } \\
(\mathrm{g})\end{array}$ & \multicolumn{2}{c}{ Displacement, $\boldsymbol{S}(\mathbf{m})$} & $\begin{array}{c}\text { IO }=\mathbf{1 \%} \\
(\mathbf{m})\end{array}$ & $\begin{array}{c}\mathbf{L S}=\mathbf{2 \%} \\
(\mathbf{m})\end{array}$ & $\begin{array}{c}\mathbf{C P}=\mathbf{4 \%} \\
(\mathbf{m})\end{array}$ \\
\hline $\mathbf{0 . 2 3 4}$ & 0.060381 & 0.018507 & $\mathbf{0 . 0 3}$ & $\mathbf{0 . 0 6}$ & $\mathbf{0 . 1 2}$ \\
$\mathbf{0 . 3 5 1}$ & 0.089083 & 0.028693 & $\mathbf{0 . 0 3}$ & $\mathbf{0 . 0 6}$ & $\mathbf{0 . 1 2}$ \\
$\mathbf{0 . 3 7 4 4}$ & 0.094937 & 0.030719 & $\mathbf{0 . 0 3}$ & $\mathbf{0 . 0 6}$ & $\mathbf{0 . 1 2}$ \\
$\mathbf{0 . 3 9 7 8}$ & 0.100812 & 0.032754 & $\mathbf{0 . 0 3}$ & $\mathbf{0 . 0 6}$ & $\mathbf{0 . 1 2}$ \\
$\mathbf{0 . 4 2 1 2}$ & 0.106752 & 0.034807 & $\mathbf{0 . 0 3}$ & $\mathbf{0 . 0 6}$ & $\mathbf{0 . 1 2}$ \\
$\mathbf{0 . 4 4 4 6}$ & 0.112583 & 0.036816 & $\mathbf{0 . 0 3}$ & $\mathbf{0 . 0 6}$ & $\mathbf{0 . 1 2}$ \\
$\mathbf{0 . 4 6 8}$ & 0.118506 & 0.038874 & $\mathbf{0 . 0 3}$ & $\mathbf{0 . 0 6}$ & $\mathbf{0 . 1 2}$ \\
\hline
\end{tabular}

Dari Tabel 7 dapat dilihat dengan menggunakan standar FEMA 356, struktur beton gedung E ITERA telah mencapai kondisi life safety pada gempa $0.234 \mathrm{~g}$ untuk joint 1128 . Dan untuk joint 709 masih berada pada kondisi immediate occupancy pada gempa $0,234 \mathrm{~g}$. Hal sama juga terjadi pada kedua joint yang ditinjau ketika dilakukan peningkatan percepatan gempa (seperti yang terlihat pada Tabel 7).

Dapat dilihat bahwa baik dengan menggunakan standar SNI peningkatan gempa hingga 2 kali gempa awal tidak mengantarkan seluruh struktur melewati simpangan izin. Dan menggunakan FEMA356 struktur beton gedung E ITERA belum ada yang mencapai kondisi collapse prevention ketika dilakukan peningkatan percepatan gempa hingga $0,468 \mathrm{~g}$ (2 kali percepatan awal gempa).

Sedangkan pada struktur baja, nilai simpangan izin yang diatur dalam SNI 1726-2012 adalah sebesar 1,5\% dari tinggi tingkat di bawah tingkat yang ditinjau. Pada struktur baja gedung E ITERA dilakukan peninjauan pada 2 titik joint berbeda yaitu joint 1128 (J1128) dan joint 709 (J709) seperti yang terlihat pada Gambar 11 terhadap batasan simpangan yang diizinkan.

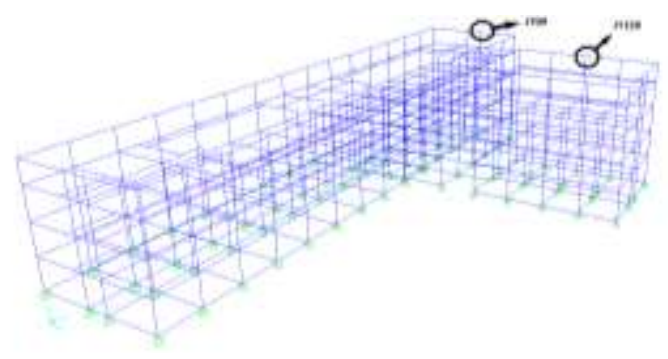

Gambar 11. Joint Struktur Baja yang Ditinjau

Tabel 8. Simpangan Struktur Baja (SNI 1726-2012)

\begin{tabular}{cccc}
\hline \multirow{2}{*}{ PGA (g) } & \multicolumn{2}{c}{ Displacement, $\boldsymbol{S}(\mathbf{m})$} & S limit (m) \\
& $\mathbf{J 1 1 2 8}$ & $\mathbf{J 7 0 9}$ & \\
\hline $\mathbf{0 . 2 3 4}$ & 0.093193 & 0.013603 & 0.045 \\
$\mathbf{0 . 3 5 1}$ & 0.135845 & 0.020395 & 0.045 \\
$\mathbf{0 . 4 6 8}$ & 0.175601 & 0.027147 & 0.045 \\
$\mathbf{0 . 5 8 5}$ & 0.213911 & 0.033686 & 0.045 \\
$\mathbf{0 . 7 0 2}$ & 0.252024 & 0.040152 & 0.045 \\
$\mathbf{0 . 7 4 8 8}$ & 0.267661 & 0.042669 & 0.045 \\
$\mathbf{0 . 7 7 2 2}$ & 0.27552 & 0.043884 & 0.045 \\
$\mathbf{0 . 7 9 5 6}$ & 0.283378 & 0.045125 & 0.045 \\
\hline
\end{tabular}

Dari data pada Tabel 8 dapat dilihat struktur baja gedung E ITERA sudah melewati nilai simpangan izin (SNI 1726-2012) pada kasus percepatan gempa $0.234 \mathrm{~g}$ di joint 1128 namun belum melewati simpangan izin pada joint 709. Ketika dilakukan peningkatan percepatan beban gempa hingga 3,3 kali percepatan awal gempa $(0,7722 \mathrm{~g})$ joint 709 masih berada pada batas simpangan izin. Barulah pada percepatan beban gempa yang sudah ditingkatkan hingga 3,4 kali $(0,7956 \mathrm{~g}) 2$ joint yang ditinjau melewati simpangan izin.

Dengan menggunakan standar pada FEMA 356 dengan batasan kondisi IO (immediate occupancy) 0.7\%, LS (life Safety) $2.5 \%$, dan CP (collapse prevention) sebesar 5 $\%$ dari tinggi tingkat di bawah tingkat yang ditinjau maka data simpangan berdasarkan FEMA 356 pada struktur baja dapat dilihat pada Tabel 9. 
Tabel 9. Simpangan Struktur Baja (FEMA 356)

melebihi CP pada output SAP (indikator sudah berwarna jingga). Dari Tabel 10 dapat dilihat

\begin{tabular}{ccccc}
$\begin{array}{c}\text { PGA } \\
(\mathbf{g})\end{array}$ & \multicolumn{2}{c}{$\begin{array}{c}\text { Displacement, } \boldsymbol{S} \\
(\mathbf{m})\end{array}$} & $\begin{array}{c}\text { IO }=\mathbf{0 . 7 \%} \\
(\mathbf{m})\end{array}$ & $\begin{array}{c}\text { LS }=\mathbf{2 . 5} \% \\
(\mathbf{m})\end{array}$ \\
\hline $\mathbf{0 . 2 3 4}$ & 0.093193 & 0.013603 & $\mathbf{0 . 0 2 1}$ & $\mathbf{0 . 0 7 5}$ \\
$\mathbf{0 . 3 5 1}$ & 0.135845 & 0.020395 & $\mathbf{0 . 0 2 1}$ & $\mathbf{0 . 0 7 5}$ \\
$\mathbf{0 . 4 6 8}$ & 0.175601 & 0.027147 & $\mathbf{0 . 0 2 1}$ & $\mathbf{0 . 0 7 5}$ \\
$\mathbf{0 . 5 8 5}$ & 0.213911 & 0.033686 & $\mathbf{0 . 0 2 1}$ & $\mathbf{0 . 0 7 5}$ \\
$\mathbf{0 . 7 0 2}$ & 0.252024 & 0.040152 & $\mathbf{0 . 0 2 1}$ & $\mathbf{0 . 0 7 5}$ \\
$\mathbf{0 . 7 4 8 8}$ & 0.267661 & 0.042669 & $\mathbf{0 . 0 2 1}$ & $\mathbf{0 . 0 7 5}$ \\
$\mathbf{0 . 7 7 2 2}$ & 0.27552 & 0.043884 & $\mathbf{0 . 0 2 1}$ & $\mathbf{0 . 0 7 5}$ \\
$\mathbf{0 . 7 9 5 6}$ & 0.283378 & 0.045125 & $\mathbf{0 . 0 2 1}$ & $\mathbf{0 . 0 7 5}$ \\
\hline & & & &
\end{tabular}

Dari Tabel 9 dapat dilihat dengan menggunakan standar FEMA 356, pada percepatan gempa awal $(0,234 \mathrm{~g})$ kondisi joint 709 masih berada pada kondisi immediate occupancy dan joint 1128 sudah berada pada kondisi life safety. Dan barulah pada percepatan beban gempa $0,468 \mathrm{~g}$ simpangan mencapai kondisi collapse prevention pada joint 1128.

Dengan demikian pada pengecekan simpangan struktur baja dengan menggunakan SNI 1726-2012 ataupun menggunakan standar FEMA356 menyatakan bahwa untuk struktur baja hanya menunjukkan salah satu dari dua joint tinjauan yang dominan sudah melampaui batas simpang izin yaitu joint 1128 .

\subsubsection{Rotasi}

Untuk kondisi nilai rotasi pada struktur beton gedung $\mathrm{E}$ ITERA dapat dilihat representasinya pada Tabel 10. Dan member yang digunakan untuk meninjau nilai rotasi pada struktur adalah member nomor 208 sesuai dengan member yang digunakan sebagai acuan pada pengecekan desain plastis struktur beton gedung E ITERA.

Tabel 10. Rotasi Struktur Beton

\begin{tabular}{|c|c|c|c|c|c|c|c|c|c|c|}
\hline \multirow{3}{*}{$\operatorname{PGA}(\mathrm{g})$} & \multicolumn{2}{|c|}{0.05} & \multicolumn{2}{|c|}{0.95} & \multirow{2}{*}{\multicolumn{2}{|c|}{ IO }} & \multirow{2}{*}{\multicolumn{2}{|c|}{$\mathrm{L}$}} & \multirow{2}{*}{\multicolumn{2}{|c|}{ CP }} \\
\hline & $\theta \max$ & $\theta \min$ & $\theta \max$ & $\theta \min$ & & & & & & \\
\hline & (rad) & (rad) & $(\mathrm{rad})$ & $(\mathrm{rad})$ & $(+)$ & $(-)$ & $(+)$ & $(-)$ & $(+)$ & $(-)$ \\
\hline 0.234 & 0.01243 & -0.01243 & 0.01459 & -0.01459 & 0.01 & -0.01 & 0.02 & -0.02 & 0.025 & -0.025 \\
\hline 0.351 & 0.01907 & -0.01907 & 0.02259 & -0.02259 & 0.01 & -0.01 & 0.02 & -0.02 & 0.025 & -0.025 \\
\hline 0.3744 & 0.02041 & -0.02041 & 0.0242 & -0.0242 & 0.01 & -0.01 & 0.02 & -0.02 & 0.025 & -0.025 \\
\hline 0.3978 & 0.02174 & -0.02174 & 0.02581 & -0.02581 & 0.01 & -0.01 & 0.02 & -0.02 & 0.025 & -0.025 \\
\hline 0.4212 & 0.02307 & -0.02307 & 0.02743 & -0.02743 & 0.01 & -0.01 & 0.02 & -0.02 & 0.025 & -0.025 \\
\hline 0.4446 & 0.02441 & -0.02441 & 0.02901 & -0.02901 & 0.01 & -0.01 & 0.02 & -0.02 & 0.025 & -0.025 \\
\hline 0.468 & 0.0257 & -0.0257 & 0.03059 & -0.03059 & 0.01 & -0.01 & 0.02 & -0.02 & 0.025 & -0.025 \\
\hline
\end{tabular}

Peningkatan percepatan awal gempa pada struktur beton dilakukan hingga $0,468 \mathrm{~g}(2 \mathrm{x}$ Aog) dikarenakan indikator sendi plastis sudah 
Tabel 12. Base Shear Struktur Beton

\begin{tabular}{cc}
\hline PGA (g) & Nilai Base Shear $(\mathbf{k N})$ \\
\hline 0.234 & 43935.725 \\
0.351 & 65555.331 \\
0.468 & 87152.566 \\
\hline
\end{tabular}

Dari data di Tabel 12 dapat diketahui nilai base shear untuk beban gempa dinamik nonlinier time history dengan percepatan awal gempa $0,234 \mathrm{~g}$ adalah sebesar $43935,725 \mathrm{kN}$ dan meningkat sesuai dengan peningkatan percepatan gempa.

Sedangkan untuk struktur baja gedung $\mathrm{E}$ ITERA, nilai base shear yang didapatkan bersamaan dengan peningkatan percepatan beban gempa dapat dilihat pada Tabel 13 berikut.

Tabel 13. Base Shear Struktur Baja

\begin{tabular}{cc}
\hline PGA (g) & Nilai Base Shear $(\mathbf{k N})$ \\
\hline 0.234 & 16419.442 \\
0.351 & 24578.178 \\
0.468 & 32548.811 \\
0.585 & 40376.121 \\
0.702 & 48169.488 \\
\hline
\end{tabular}

Pada struktur baja gedung E ITERA untuk beban gempa dinamik nonlinier time history dengan percepatan awal gempa $0,234 \mathrm{~g}$ didapatkan nilai base shear dinamik sebesar 16419,442 kN. Begitu juga seterusnya ketika terjadi peningkatan percepatan gempa awal (seperti yang dapat dilihat pada Tabel 13).

Gaya geser dasar ini merupakan hasil analisis gaya geser dinamik dengan kombinasi pembebanan yang paling dominan yaitu time history kombinasi. Dan dari kedua data di atas dapat disimpulkan bahwa base shear dinamik struktur beton dan struktur baja dipengaruhi oleh adanya peningkatan percepatan awal gempa (Aog). Selain itu nilai base shear struktur beton yang lebih besar dibandingkan struktur baja akan menyebabkan biaya struktur bawah yang lebih mahal karena dibutuhkan struktur bawah yang lebih kuat ( untuk kondisi tanah yang sama).

\section{KESIMPULAN}

Kesimpulan yang didapat dari hasil penelitian ini adalah sebagai berikut :

1. Pada struktur beton gedung E ITERA bagian struktur yang terlebih dahulu mengalami kegagalan ketika diberikan beban gempa dinamik nonlinier adalah balok arah y dengan nomor nomor 208 serta ukuran penampang 250x500 mm (bxh). Dan pada struktur baja gedung E ITERA bagian struktur yang terlebih dahulu mengalami kegagalan ketika diberikan beban gempa dinamik nonlinier adalah balok nomor 120 dengan penampang profil IWF 300x150 mm.

2. Gempa maksimum yang dapat ditahan struktur beton gedung E ITERA adalah sebesar 1,9 kali percepatan gempa awal $(0,4446 \mathrm{~g})$. Dan pada struktur baja gedung E ITERA beban gempa maksimum yang dapat ditahan adalah sebesar 3,3 kali percepatan gempa awal $(0,7722 \mathrm{~g})$.

\section{SITASI DAN DAFTAR PUSTAKA}

[1] Budiono, Bambang dan Lucky Supriatna, Studi Komparasi Desain Bangunan Tahan Gempa, Bandung : ITB, 2011

[2] SNI 1726:2012, Tata Cara Perencanaan Ketahanan Gempa untuk Struktur Bangunan Gedung dan Non Gedung, Badan Standarisasi Indonesia : Jakarta. 2012

[3] Anggen, Wandrianto S, Evaluasi Kinerja Struktur Gedung Bertingkat Dengan Analisis Dinamik Time History Menggunakan Etabs Studi Kasus : Hotel di Karanganyar [skripsi], Teknik Sipil Fakultas Teknik Universitas Sebelas Maret, 2014

[4] Chopra, A. K, Dynamic of Structures Theory and Applications to Earthquake Engineering, Pearson, 2011

[5] FEMA-356, Prestandard and Commentary For The Seismic Rehabilitation Of Buildings, Virginia : American Society of Civil Engineers, 2000

[6] Ulfah, Atika, Evaluasi Kinerja Struktur Gedung Kuliah Umum Sardjito, Magister Teknik Sipil Universitas Islam Indonesia : Yogyakarta, 2011

[7] Imran, I. dan Hendrik, F, Perencanaan Struktur Gedung Beton Bertulang Tahan Gempa. Bandung: Penerbit ITB, 2010 